\title{
Investigation of phytochemical constituents, phenolic profiles and antioxidant activities of ricegrass juice compared to wheatgrass juice
}

\section{Rattanamanee Chomchan ${ }^{1}$, Sunisa Siripongutikorn ${ }^{2}$, Panupong Puttarak ${ }^{3}$, and Rungtip Rattanapon ${ }^{2}$}

${ }^{1}$ Interdisciplinary Graduated School of Nutraceutical and Functional Food, Prince of Songkla University, Hat-Yai, Songkla 90112, Thailand; ${ }^{2}$ Department of Food Technology, Faculty of Agro-Industry, Prince of Songkla University, Hat-Yai, Songkla 90112, Thailand; ${ }^{3}$ Department of Pharmacognosy and Pharmaceutical Botany, Faculty of Pharmaceutical Sciences, Prince of Songkla University, Hat-Yai, Songkhla 90112, Thailand

Corresponding author: Sunisa Siripongvutikorn, PhD., Asst. Prof., Department of Food Technology, Faculty of Agro-Industry, Prince of Songkla University, Hat-Yai, Songkla 90112, Thailand

Submission Date: September 5, 2016, Accepted Date: December 28, 2016, Publication Date: December 30,2016

Citation: Chomchan R., Siripongvutikorn S., Puttarak P, and Rattanapon R. Investigation of phytochemical constituents, phenolic profiles and antioxidant activities of ricegrass juice compared to wheatgrass juice. Functional Foods in Health and Disease 2016; 6(12):822-835

\begin{abstract}
Background: Cereal grass has been brought attention as a new functional food. Wheatgrass juice was known as a super food which provides lots of advantages for human health. However, the young stage of rice sprout has not been made widely known for consumption, though it is in the similar family to wheat (Poaeceae). Accordingly, ricegrass juice can and should be introduced, especially in Asian countries, as an economical functional drink. Nevertheless, currently there is none of the apparent evidences which confirm the nutritive values of ricegrass juice compared to wheatgrass juice.
\end{abstract}

Objective: To investigate the chemical compositions, major phytochemical constituents, bioactive compounds content, specific phenolic profiles, and in vitro antioxidant activities of ricegrass juice compared to wheatgrass juice.

Methods: Rice and wheat seeds were germinated and grown hydroponically for 8 days. Both fresh plants were determined for chemical compositions. Next, the grasses were extracted with water, centrifuged, and the supernatants were tested for chlorophyll, carotenoid, and ascorbic acid contents. The left-over supernatant were freeze-dried. The extracts were then screened for 
the main group of phytochemicals, total extractable phenolic and specific phenolic compounds. Lastly, the extracts were tested for the antioxidant activities using DPPH, ABTS, FRAP, FCA and HRSA.

Results: Data revealed that wheatgrass contained higher levels of protein and fat. Both ricegrass and wheatgrass juice extract exhibited the group of phenol, tannin and saponin but not alkaloid, flavonoid, sterol, terpenoid, courmarin, and cardiac glycoside. Wheatgrass juice can be detected for higher level of ascorbic acid and chlorophyll. Both grass juices were found the similar phenolic acids analyzed by HPLC included pyrogallol, vanilic acid, syringic acid and ferulic acid, however, ricegrass juice contained larger amounts of all phenolic acids excluding syringic acid. Conversely, wheatgrass juice exposed higher antioxidant activities for all methods. This may propose from the synergistic effects of ascorbic acid, chlorophyll, and phenolic compounds in wheatgrass juice, while the main composites exhibited antioxidant activities in ricegrass were phenolic compounds.

Conclusion: Ricegrass juice contained great level of phenolic acid molecules. Even if ricegrass juice gave less statistically ability on antioxidant activities, they still had comparable levels of antioxidant activities. With the reduction in cost of raw materials and contribution of high nutritional values, ricegrass juice could be introduced as an antioxidant boosting drink in competition to wheatgrass juice.

Keywords: Antioxidant, Phytochemical, Phenolic compounds, Ricegrass, Wheatgrass

\section{BACKGROUND:}

Plants are important sources of natural remedies which have been used by human for ages since they contain many biologically active compounds, for example, polyphenols, vitamins, terpenes, organic acids, etc. that work vigorously against several kinds of diseases such as cancer, atherosclerosis, diabetes, and many more [1]. In the recent years, young cereal sprouts have been getting increasing attention as a new potent plant for consumption as vegetables because the sprouting stage is believed to be the stage that plants contain the highest content of readily available compounds such as amino acids, vitamins, and enzymes since after this stage plant starts to use these compounds to produce cellulose as a structure of growing stems [2]. Additionally, plants at young stage produce high level of phytochemicals substances to protect themselves from danger and these compounds exert various biological benefits to human health. Therefore, sprout, being a fresh, simple, and full of nutrition vegetable, can be suggested as a good choice of healthy eating diet. Furthermore, the consumption of sprout juice is prominent, as it is a simple manner to supplement the powerful nutritive and advantageous compounds in small quantities.

Wheatgrass juice (Triticum aestivum L.) is the most popular consumed sprout juice over the world. It has been widely investigated for lots of pharmaceutical effects on human health, including blood builder agents for thalassemia, detoxifying agents, antioxidant substances, and possible use as anti-inflammatory and anti-cancer substances [3]. However, wheat is mostly grown in the low temperature zones include some parts of United States, Canada, and Europe. 
For Asian countries, rice (Oryza sativa L.) is the principal energy food source. Thus, there is the plentiful resource of rice which is a lower cost ingredient than wheat in this region. In the same manner, rice is one of the cereal plants in grass family (Poaceae) similar to that of wheat, rye, and barley. Some literacies also reported on discovering phenolic compounds and some biological properties such as antioxidant properties and DNA protective properties in ricegrass juice $[4,5]$. Consequently, the introduction of the young ricegrass juice as an innovative functional drink is fascinating. Moreover, it can offer the added value for some rice cultivars which their grains are low in price because of low palatability, hard texture, being less fragile, and lack of identity.

However, rice sprouts or ricegrass at a young stage still have not been widely consumed as food. There is no report to prove whether the amount of bioactive molecules and biological properties of young ricegrass juice is in comparison to that of wheatgrass juice. Moreover, little is known on type of phytochemical constituents as well as specific phenolic compounds found in both young ricegrass and wheatgrass. Therefore, this study aimed to investigate the chemical composition of fresh ricegrass and wheatgrass, as well as determine the type of phytochemical constituents, bioactive compound contents, the presence of specific phenolic compounds using HPLC and in vitro antioxidant activities of ricegrass juice compared to wheatgrass juice.

\section{MATERIALS AND METHODS:}

Plant materials: Rice seeds (Oryza sativa L. cv. Chainat1) obtained from Patthalung Rice Research Center, Thailand and wheat seeds (Tirticum aestivum L. cv. Fang60) were soaked in water for 24 hours to stimulate the germination. After rinse the water, seeds were placed in the plantation tray with moist and allowed to germinate for 48 hours. Germinated seeds were grown hydroponically without any supporting materials and fertilization under natural light with a day/night average temperature of $32 / 25^{\circ} \mathrm{C}$, relative humidity $65 \pm 8.5 \%$ in partially close system. Plants were watered twice a day and harvested at day 8 .

Chemical compositions: The chemical composition of fresh ricegrass and wheatgrass included moisture, protein, fat, carbohydrate, ash, and fiber contents of samples were analyzed followed the method of AOAC [6]. Total sugar content was determined using phenol sulfuric method described by Dubois et al. [7]. Total reducing sugar content was measured using Nelson's method [8]. Glucose was used as the standard for both total sugar and total reducing sugar determination at the range $20-100 \mu \mathrm{g} / \mathrm{ml}$.

Extraction procedure: Ricegrass and wheatgrass were extracted with water at ratio of 1:2(w/v) using juicer machine (Hurom DA-900) at room temperature. The sample was filtered with Whatman No. 4 filter paper to get rid of residues and followed by centrifugation at 10,000 xg for 20 minutes. Fresh juices were tested for some chemical analysis. The others were subjected to freeze drying then stored at $4^{\circ} \mathrm{C}$.

Phytochemical screening: Freeze dried powder of ricegrass and wheatgrass juice $(10 \mathrm{mg} / \mathrm{ml})$ were tested for the presence of numerous phytochemical constituents following the methods described by Sofowora [11] and Harborne [12]. 
Alkaloid test; $1 \mathrm{ml}$ extract was added with $5 \mathrm{ml}$ of $1 \%$ hydrochloric acid and heated on steam bath at $60^{\circ} \mathrm{C}$ for 15 minutes. After filtration, $1 \mathrm{ml}$ filtrate was separated into 3 tubes. $1 \mathrm{ml}$ of Dragendorff's reagent, Mayer's reagent and Wagner's reagent were added to each tube. The orange, yellow and turbid brown color precipitate indicated the presence of alkaloid.

Phenol and Tannin test; $1 \mathrm{ml}$ of the extract was added with $1 \mathrm{ml}$ of $3 \% \mathrm{FeCl}_{3}$ was added. Formation of greenish black indicated the presence of hydrolyzed tannin including phenol or blue color indicated the presence of condensed tannin.

Flavonoid test; $2 \mathrm{ml}$ of the extract was dissolved in $3 \mathrm{ml}$ of $50 \%$ ethanol. Magnesium turnings were put in the tube and boiled for 30 minutes. Then 2 drops of concentrated $\mathrm{HCl}$ was added. Pink color formation specified the presence of flavonoid.

Terpenoid test; $5 \mathrm{ml}$ of the extract was mixed with $2 \mathrm{ml}$ chloroform and carefully added with $3 \mathrm{ml}$ concentrated $\mathrm{H}_{2} \mathrm{SO}_{4}$. A reddish brown coloration between upper and lower layer revealed the presence of terpenoid.

Sterol test; $2 \mathrm{ml}$ of extract was added with $2 \mathrm{ml}$ of concentrated $\mathrm{H}_{2} \mathrm{SO}_{4}$. Red precipitation indicated the presence of steroidal ring.

Saponin test; $2 \mathrm{ml}$ of the extract was mixed with $5 \mathrm{ml}$ of distilled water and shaken vigorously for $5 \mathrm{~min}$. Persistence of foams for 30 minutes indicated the presence of saponin.

Coumarin test; Filter paper was soaked in $10 \% \mathrm{NaOH}$ and hang upon the tube containing 5 $\mathrm{ml}$ of the extract and evaporated for 30 minutes in water bath. The soaked filter paper was examined after placing under UV light for $10 \mathrm{~min}$. Fluorescence spot indicated the presence of coumarin.

Cardiac-glycoside test; $0.5 \mathrm{ml}$ of extract was dissolved in $1 \mathrm{ml}$ glacial acetic acid containing 1 drop of $1 \% \mathrm{FeCl}_{3}$, then added with $1 \mathrm{ml}$ of concentrated $\mathrm{H}_{2} \mathrm{SO}_{4}$. The formation of brown ring at the interface indicated the positive result.

Ascorbic acid content: Ascorbic acid content of grasses juice was analyzed using indo-phenol colorimetric method [6]. The juice was diluted with $2 \%$ meta-phosphoric acid to the appropriate concentration. $5 \mathrm{ml}$ of diluted samples were added with $10 \mathrm{ml}$ of $1.7 \mathrm{mM} \mathrm{2,6}$ di-chloroindophenol solution, mixed well and measured for the absorbance using spectrophotometer at $518 \mathrm{~nm}$. Ascorbic acid $(0-400 \mu \mathrm{g} / \mathrm{ml})$ was used as standard.

Chlorophyll and carotenoid content: The total chlorophyll, chlorophyll a $\left(\mathrm{C}_{\mathrm{a}}\right)$ and chlorophyll $\mathrm{b}\left(\mathrm{C}_{\mathrm{b}}\right)$ were analyzed using the defined method of Arnon [9]. Carotenoid was calculated using Lichtenthaler and Wellburn [10] equation. Briefly, 0.5 to $1 \mathrm{ml}$ of grasses juice were made up with $80 \%$ acetone to the volume of $10 \mathrm{ml}$. The mixtures were then centrifuged at $5000 \times \mathrm{xg}$ for 2 minutes. The absorbance of supernatants were measured with spectrophotometer at 470, 645, $663 \mathrm{~nm}$. The concentration of pigments was calculated from the following equations when $\mathrm{A}$ is absorbance (nm):

Total chlorophyll $=20.2\left(\mathrm{~A}_{645}\right)+8.02\left(\mathrm{~A}_{663}\right)$

Chlorophyll a $\left(\mathrm{C}_{\mathrm{a}}\right)=12.7\left(\mathrm{~A}_{663}\right)+2.69\left(\mathrm{~A}_{645}\right)$

Chlorophyll b $\left(\mathrm{C}_{\mathrm{b}}\right)=22.9\left(\mathrm{~A}_{645}\right)-4.68\left(\mathrm{~A}_{663}\right)$

Carotenoid $=\left(1000\left(\mathrm{~A}_{470}\right)-3.27 \mathrm{C}_{\mathrm{a}}-104 \mathrm{C}_{\mathrm{b}}\right) / 229$ 
Total extractable phenolic content (TPC): The total extractable phenolic content of the extracts were measured using a Folin-Ciocalteu method from Singleton and Rossi [13]. Concisely, $20 \mu \mathrm{l}$ of the extract was added to 96-well micro-plate. Next, $100 \mu 1$ of Folin-Ciocalteu reagent $(10 \% \mathrm{v} / \mathrm{v})$ and $80 \mu \mathrm{l}$ of $\mathrm{Na}_{2} \mathrm{CO}_{3}(7.5 \% \mathrm{w} / \mathrm{v})$ were added and mixed thoroughly. After incubation for 30 minutes in the dark at ambient temperature, the absorbance was measured at $765 \mathrm{~nm}$ using the micro-plate reader. The total phenolic content was expressed as $\mathrm{mg}$ of pyrogallol equivalent (PYE)/g extract $(20-80 \mu \mathrm{g} / \mathrm{ml})$.

HPLC analysis: Both aqueous ricegrass and wheatgrass extract were acidic hydrolyzed using $6 \mathrm{M} \mathrm{HCl}$ at $70^{\circ} \mathrm{C}$ for 3 hours before the analysis. HPLC-DAD investigation was performed on a 1200 Agilent technologies HPLC system (Germany). Reversed phase chromatographic analyses were carried out under gradient conditions using a C-18 column $(250 \mathrm{~mm} \times 4.6 \mathrm{~mm})$ packed with $5 \mu \mathrm{m}$ diameter particles. The phenolic profiles were carried out using HPLC water containing $0.1 \%$ trifluoroacetic acid (solvent $\mathrm{A}$ ) and acetonitrile (solvent $\mathrm{B}$ ). The elution profile had the following proportion of acetonitrile (v/v): $0.00-10.00 \mathrm{~min}, 0 \%-10.0 \% ; 10.00-15.00 \mathrm{~min}$, $10.0 \%$; 15.00-20.00 min, $10.0 \%-15.0 \% ; 20.00-30.00 \mathrm{~min}, 15.0 \%-25.0 \% ; 30.00-35.00 \mathrm{~min}$, $25.0 \% ; 35.00-50.00 \mathrm{~min} ; 25.0 \%-0 \%$. The flow rate was $0.8 \mathrm{ml} / \mathrm{min}$ at the temperature $40{ }^{\circ} \mathrm{C}$ with the injection volume of $20 \mu \mathrm{l}$. Identification of phenolics was performed by comparing retention times with those of standards. Stock solutions of pyrogallol, protocatechuic acid, catechin, chlorogenic acid, vanillic acid, caffeic acid, syringic acid, courmaric acid, and ferulic acid were prepared and run for a linear equation. Quantification was performed by peak integration.

\section{Antioxidant activities:}

\section{DPPH radical scavenging activity}

2,2-diphenyl-1-picryl hydrazyl (DPPH) radical scavenging activity was determined using the modified method of Brand-Williams et al. [14]. Briefly, $150 \mu \mathrm{l}$ of the extract was added with 150 $\mu 1$ of $0.2 \mathrm{mM} \mathrm{DPPH}$ in $95 \%$ ethanol. The mixture was mixed and stand for 30 minutes in the dark. The absorbance was determined at $517 \mathrm{~nm}$ using the micro-plate reader. Standard curves of pyrogallol and Trolox with concentration 1-5 $\mu \mathrm{g} / \mathrm{ml}$ and $1-10 \mu \mathrm{g} / \mathrm{ml}$ were prepared, respectively. The activity was reported as mg pyrogallol equivalent (PYE)/g extract and Trolox equivalent (TE)/g extract.

\section{ABTS radical scavenging activity}

2,2-azino-bis-3-ethylbenzthiazoline-6-sulphonic acid (ABTS) assay was determined follow the the method of Arnao et al. [15]. The stock solutions of $7.4 \mathrm{mM}$ ABTS solution and $2.5 \mathrm{mM}$ $\mathrm{K}_{2} \mathrm{~S}_{2} \mathrm{O}_{8}$ solution were prepared. The ABTS radical solution was generated by mixing both stock solutions in equal quantities and allowing them to react for 12 hours at room temperature in the dark. The radical solution was diluted to obtain an absorbance of $1.1 \pm 0.02$ at $734 \mathrm{~nm}$ before performing the assay. $15 \mu \mathrm{l}$ of extract was mixed with $285 \mu \mathrm{l}$ of ABTS radical solution and left at room temperature for 2 hours in the dark. The absorbance was measured at $734 \mathrm{~nm}$ using the micro-plate reader. Standard curves of pyrogallol and Trolox with concentration $5-25 \mu \mathrm{g} / \mathrm{ml}$ and 
$10-100 \mu \mathrm{g} / \mathrm{ml}$ were prepared, respectively. The activity was reported as $\mathrm{mg}$ pyrogallol equivalent (PYE)/g extract and Trolox equivalent (TE)/g extract.

\section{Ferric reducing antioxidant power (FRAP)}

The ferric reducing antioxidant power (FRAP) assay was performed according to method of Benzie and Strain [16]. FRAP solution was freshly prepared from the mixture of $300 \mathrm{mM}$ acetate buffer pH 3.6, $10 \mathrm{mM}$ TPTZ (2, 4, 6- tripyridyl-s-triazine) solution in $40 \mathrm{mM} \mathrm{HCl}$ and $20 \mathrm{mM}$ $\mathrm{FeCl}_{3} \cdot 6 \mathrm{H}_{2} \mathrm{O}$ solution at the ratio $10: 1: 1(\mathrm{v} / \mathrm{v} / \mathrm{v})$ and then warmed at $37^{\circ} \mathrm{C}$ for 30 minutes before use. $15 \mu$ l extract was added with $285 \mu$ l of FRAP solution and stand for 30 minutes in the dark. The absorbance was read at $593 \mathrm{~nm}$ using micro-plate reader. Standard curves of pyrogallol and Trolox with concentration $1-10 \mu \mathrm{g} / \mathrm{ml}$ and $10-100 \mu \mathrm{g} / \mathrm{ml}$ were prepared, respectively. The activity was reported as mg pyrogallol equivalent (PYE)/g extract and Trolox equivalent (TE)/g extract.

\section{Ferrous ion chelating activity (FCA)}

Ferrous ion chelating activity was determined using the method of Ebrahimzadeh et al. [17]. $277.5 \mu \mathrm{l}$ of extract was mixed with $7.5 \mu \mathrm{l}$ of $2 \mathrm{mM} \mathrm{FeCl}_{2}$ and $15 \mu \mathrm{l}$ of $5 \mathrm{mM}$ ferrozine for 10 minutes at room temperature. The absorbance was read at $562 \mathrm{~nm}$ using micro-plate reader. A standard curve of EDTA at concentration $20-40 \mu \mathrm{g} / \mathrm{ml}$ was prepared. The activity was expressed as mg EDTA equivalent (EDTAE)/g extract.

\section{Hydroxyl radical scavenging activity (HRSA)}

The hydroxyl radical scavenging activity was measured according to the method of Jin et al. (18). Briefly, $1 \mathrm{ml}$ of extract was mixed with $1 \mathrm{ml}$ of $1.865 \mathrm{mM} \mathrm{1,10-phenanthroline} \mathrm{solution}$

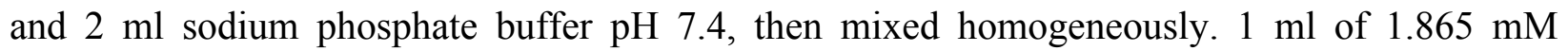
$\mathrm{FeSO}_{4} \cdot 7 \mathrm{H}_{2} \mathrm{O}$ solution was then pipetted to the mixture. The reaction was initiated by adding $1 \mathrm{ml}$ of $\mathrm{H}_{2} \mathrm{O}_{2}(0.03 \% \mathrm{v} / \mathrm{v})$. After incubation at $37^{\circ} \mathrm{C}$ for 60 minutes in a water bath, the absorbance of the sample was read at $536 \mathrm{~nm}$ against reagent blank. Standard curves of both pyrogallol and Trolox with concentration $20-100 \mu \mathrm{g} / \mathrm{ml}$ and $100-1000 \mu \mathrm{g} / \mathrm{ml}$ were prepared, respectively. The activity was reported as mg pyrogallol equivalent (PYE)/g extract and Trolox equivalent (TE)/g extract.

Statistical analysis: Completely randomized design was used in this experiment. All data were subjected to the statistical analysis using paired sample t-test. Statistical analyses were carried out using the SPSS statistical software (SPSS, Inc., Chicago. IL).

\section{RESULTS AND DISCUSSION:}

Chemical compositions: The chemical compositions of ricegrass and wheatgrass are presented in Table 1. Significant differences $(\mathrm{p}<0.05)$ in crude protein, fat, carbohydrate, ash, and sugar contents were observed among these two plants. The difference may attribute to the genetic variation in each plant [19]. Wheatgrass contained higher level of protein and fat than ricegrass. Ricegrass had higher level of carbohydrates than wheatgrass, nevertheless lower in total sugar and reducing sugar content. However, the percentage of crude fiber, which was accounted for a 
part of carbohydrate, did not demonstrate significant difference $(p<0.05)$. Therefore, it was predicted that ricegrass mainly composed of carbohydrate in the form of starch. Additionally, the observation of both plant physical characteristics revealed that ricegrass leaves were more rigid and tough rather than wheatgrass leaves, this may due to the accumulation of higher insoluble fiber such as cellulose, hemicellulose, and lignin. Ash percentage of ricegrass appeared slightly higher than wheatgrass which may build up from large amount of minerals in rice pericarp.

Table 1. Proximate composition of fresh ricegrass and wheatgrass

\begin{tabular}{llcl}
\hline Composition & Unit & Ricegrass & Wheatgrass \\
\hline Moisture content & \% FW & $77.65 \pm 0.16^{\mathrm{b}}$ & $85.28 \pm 0.30^{\mathrm{a}}$ \\
Crude protein & \% DW & $23.27 \pm 0.52^{\mathrm{b}}$ & $30.73 \pm 0.62^{\mathrm{a}}$ \\
Crude fat & \% DW & $9.91 \pm 0.60^{\mathrm{b}}$ & $14.53 \pm 0.74^{\mathrm{a}}$ \\
Ash & \% DW & $5.58 \pm 0.72^{\mathrm{a}}$ & $4.49 \pm 0.12^{\mathrm{b}}$ \\
Total carbohydrate & \% DW & $61.24 \pm 0.65^{\mathrm{a}}$ & $50.25 \pm 0.57^{\mathrm{b}}$ \\
Crude fiber & \% DW & $22.91 \pm 0.59^{\mathrm{a}}$ & $22.42 \pm 0.66^{\mathrm{a}}$ \\
Total sugar & mg GluE/ g FW & $8.48 \pm 0.09^{\mathrm{b}}$ & $15.34 \pm 0.07^{\mathrm{a}}$ \\
Reducing sugar & mg GluE/ g FW & $5.30 \pm 0.05^{\mathrm{b}}$ & $9.67 \pm 0.04^{\mathrm{a}}$ \\
\hline
\end{tabular}

Each value was expressed as the mean \pm standard deviation $(n=3)$. Different letters in the same row indicated significant differences $(\mathrm{p}<0.05)$ and ${ }^{\mathrm{a}}$ indicated higher content than ${ }^{\mathrm{b}}$. DW: dry weight. FW: fresh weight. GluE: glucose equivalent.

Phytochemical screening: The qualitative phytochemical screening of ricegrass and wheatgrass juice was performed on 8 groups of compounds (Table 2). It was found that both ricegrass and wheatgrass juice extract contained the group of phenol, tannin, and saponin but not alkaloid, flavonoid, terpenoid, sterol, cardiac glycoside, and courmarin. Results indicated the presence of similar phytochemical groups in both grasses. As the juices were extracted using water which is high polarity solvent, most of compounds dissolved in the juice were hydrophilic molecules. It has been reported earlier that tannin, soluble phenolic compounds, and saponin were presented in the solution using water as solvent [20]. Though some of less polar compounds may be partially extracted from the mechanical forces while juicing, only small amount of compounds cannot be detected from those coloration and precipitation tests. As these procedures require large amount of compounds to exhibit positive results, results in this study were not consistent to the study of Ashok [21], who reported that 8 days grown wheatgrass juice contained alkaloid, in addition to another study from Durairaj et al. [22] who stated that alkaloid, flavonoid, and terpenoid were found in the juice produced from dried powder wheatgrass. This may due to several reasons such as raw material preparation, extraction method, age and variety of plant, plantation condition, fertilizer, and irrigation. 
Table 2. Phytochemical screening of aqueous extracted ricegrass and wheatgrass

\begin{tabular}{lcc}
\hline Constituent & $\begin{array}{c}\text { Ricegrass juice } \\
\text { extract }\end{array}$ & $\begin{array}{c}\text { Wheatgrass juice } \\
\text { extract }\end{array}$ \\
\hline Alkaloid & - & - \\
Phenol and tannin & + & + \\
Flavonoid & - & - \\
Terpenoid & - & - \\
Sterol & - & - \\
Saponin & + & + \\
Coumarins & - & - \\
Cardiac glycoside & - & - \\
\hline
\end{tabular}

Remark: (+): Positive, (-): Negative

Bioactive compounds content: The content of bioactive compounds found in ricegrass juice compared to wheatgrass juice is shown in Table 3. Wheatgrass juice contained the greater level of total chlorophyll, chlorophyll a and chlorophyll $b$ to ricegrass juice. This was supported by the large amount of amino acids present in wheat seeds. As is already known, amino acids play a major role for chlorophyll biosynthesis [23[. High levels of chlorophyll which exhibited dark green color to wheatgrass were claimed to possess outstanding benefits as a blood builder agent due to the structure of chlorophyll was closely related to heme molecules in the blood [3]. While ricegrass proposed their color as light green-yellow, which may due to the enclosing in lower amount of chlorophyll and containing higher amount of carotenoids. Additionally, accumulation of higher chlorophyll found in wheatgrass may due to its originality genetic variation. Wheat is a plant naturally grown in dry and temperate zone with lower light intensity. Thus, it possibly needs to produce and accumulate condensed amount of pigments to absorb light in order to supply sufficient energy for the survival, while ricegrass, which is the tropical plants was naturally faced with higher light intensity, thereby acccumulates lower amount of chlorophyll.

Wheatgrass juice comprised twice amount of ascorbic acid (vitamin C) to ricegrass juice, which may relate to higher accumulation of sugar which was a substrate for the production of ascorbic acid. The total extractable phenolic content (TPC) of both grasses were studied using Folin-caocalteu method. Wheatgrass exhibited marginally higher level of TPC expressed as mg pyrogallol equivalent/g extract. However, it was found that this method was the nonspecifically reaction to phenolic molecules. There were some scientific data which pointed out that reducing sugars, some compounds such as ascorbic acid, amino acids, organic acids, and Fe(II) molecules can interfere with the Folin-Ciocalteu analysis and draw back to the over estimation of phenolic compounds [24]. Due to the great amount of reducing sugar and ascorbic acid in wheatgrass, the level of TPC may not indicate the actual amount of phenolic molecules in the samples. Thus, the study was subjected to further analyze for the specific compounds using HPLC. 
Table 3. Bioactive compounds content of ricegrass and wheatgrass juice

\begin{tabular}{llll}
\hline & \multicolumn{1}{c}{ Unit } & Ricegrass & Wheatgrass \\
\hline Total chlorophyll & $\mathrm{mg} / \mathrm{g} \mathrm{FW}$ & $0.427 \pm 0.005^{\mathrm{b}}$ & $2.827 \pm 0.003^{\mathrm{a}}$ \\
Chlorophyll a & $\mathrm{mg} / \mathrm{g} \mathrm{FW}$ & $0.351 \pm 0.003^{\mathrm{b}}$ & $2.135 \pm 0.031^{\mathrm{a}}$ \\
Chlorophyll b & $\mathrm{mg} / \mathrm{g} \mathrm{FW}$ & $0.136 \pm 0.003^{\mathrm{b}}$ & $1.112 \pm 0.015^{\mathrm{a}}$ \\
Carotenoids & $\mathrm{mg} / \mathrm{g} \mathrm{FW}$ & $0.063 \pm 0.002^{\mathrm{a}}$ & $0.051 \pm 0.012^{\mathrm{b}}$ \\
Ascorbic acid & $\mathrm{mg} / \mathrm{g} \mathrm{FW}$ & $0.243 \pm 0.002^{\mathrm{b}}$ & $0.487 \pm 0.020^{\mathrm{a}}$ \\
Total extractable phenolic & $\mathrm{mg} \mathrm{PYE} / \mathrm{g}$ extract & $31.44 \pm 0.44^{\mathrm{b}}$ & $33.74 \pm 0.34^{\mathrm{a}}$ \\
\hline
\end{tabular}

Each value was expressed as the mean \pm standard deviation $(n=3)$. Different letters in the same row indicated significant differences $(\mathrm{p}<0.05)$. FW: fresh weight. PYE: pyrogallol equivalent.

HPLC qualitative and quantitative of phenolic compound profile: The chromatogram of phenolic compounds detected in both ricegrass juice and wheatgrass juice extracts compared to nine external standards are shown in the Figure 1.
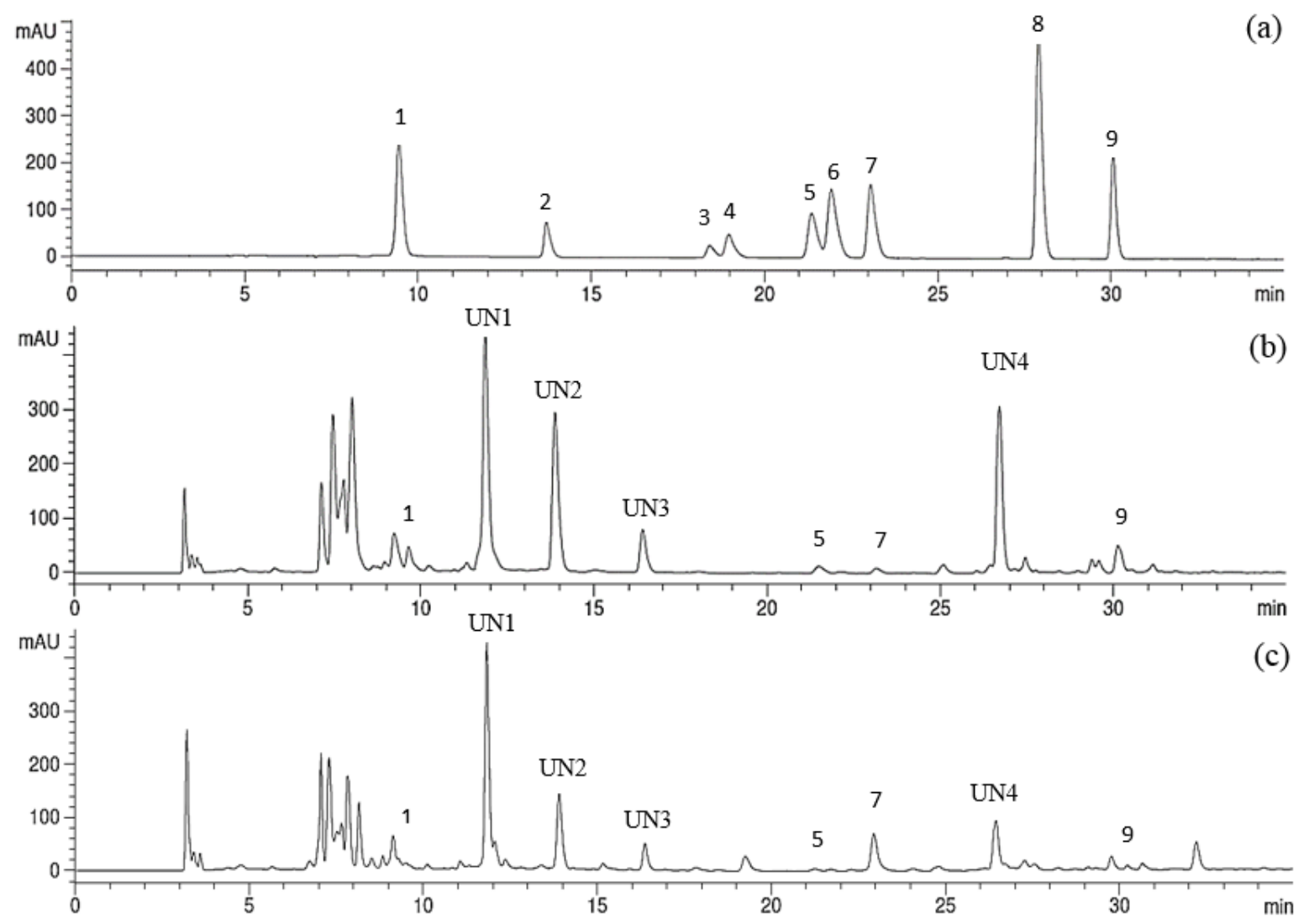

Figure 1: HPLC Chromatogram of (a) Standard phenolic compounds. Peaks: 1-pyrogallol; 2-protocatechuic acid; 3-catechin; 4-chlorogenic acid; 5-vanillic acid; 6-caffeic acid; 7-syringic acid; 8- $p$ courmaric acid; 9-ferulic acid. (b) Ricegrass aqueous extract (c) Wheatgrass aqueous extract detected at $280 \mathrm{~nm}$. UN: unknown compounds 
According to the HPLC qualitative results, four similar phenolics compounds noticed in both ricegrass and wheatgrass juices were pyrogallol, vanillic acid, syringic acid, and ferulic acid. Additionally, the pattern of other unknown compounds (UN) in both grasses were mostly alike. However, the type of foremost phenolic compounds found were still unknown (UN1UN4). To sum up, the majority phenolic compounds found in both grass juices were phenolic acids while flavonoid compounds were authorized not to notice using this specifically method (data not shown). The similar in the types of compounds of both plants may attribute to the similar family which plants belong to, accordingly containing assemble substrates in the seeds and generate closely related molecules.

The quantitative of specific phenolic compounds of the juice from ricegrass and wheatgrass detected by HPLC-DAD are shown in Table 4. Identified ricegrass juice extract was significantly $(p<0.05)$ higher level of pyrogallol, vanillic acid and ferulic acid while wheatgrass juice extract contained greater amount of syringic acid. Moreover, the prominent unknown compounds (UN1-UN4) found in ricegrass juice were significantly observed for the greater peak area, rather than wheatgrass juice which demonstrated the huge amount of existing phenolics. Thus, it can be concluded that ricegrass juice enclosed with outstanding content of phenolic acids exceeding to wheatgrass. When related to TPC data, it can be confirmed that TPC data alone may lead to untruthful interpretation on phenolic compounds content which significantly related to antioxidant activity.

Table 4: Retention time and concentration of specific phenolic compounds of acidic hydrolyzed of aqueous extracted ricegrass and wheatgrass as detected by HPLC-DAD

\begin{tabular}{cccccc}
\hline Phenolic & $\boldsymbol{K}_{\max }$ & \multicolumn{2}{c}{ Ricegrass juice extract } & \multicolumn{2}{c}{ Wheatgrass juice extract } \\
\cline { 3 - 6 } compounds & $(\mathbf{n m})$ & $\mathbf{R T}$ & $\mathbf{C o n c}$ & $\mathbf{R T}$ & Conc. \\
& & $(\mathbf{m i n})$ & $\mathbf{( m g / g )}$ & $(\mathbf{m i n})$ & $\mathbf{( m g / g )}$ \\
\hline Pyrogallol & 267 & $9.452 \pm 0.009^{\mathrm{A}}$ & $10.382 \pm 0.03^{\mathrm{a}}$ & $9.494 \pm 0.001^{\mathrm{A}}$ & $4.084 \pm 0.092^{\mathrm{b}}$ \\
Vanillic acid & 280 & $21.096 \pm 0.108^{\mathrm{A}}$ & $0.641 \pm 0.015^{\mathrm{a}}$ & $21.192 \pm 0.082^{\mathrm{A}}$ & $0.394 \pm 0.008^{\mathrm{b}}$ \\
Syringic acid & 280 & $22.811 \pm 0.087^{\mathrm{A}}$ & $0.604 \pm 0.009^{\mathrm{b}}$ & $22.863 \pm 0.028^{\mathrm{A}}$ & $1.416 \pm 0.016^{\mathrm{a}}$ \\
Ferulic acid & 320 & $29.905 \pm 0.005^{\mathrm{A}}$ & $0.062 \pm 0.001^{\mathrm{a}}$ & $29.990 \pm 0.007^{\mathrm{A}}$ & $0.044 \pm 0.001^{\mathrm{b}}$ \\
\hline
\end{tabular}

Each value was expressed as the mean \pm standard deviation. Different capital letters indicated significant differences in retention time $(p<0.05)$. Different small letters indicated significant differences in concentration $(p<0.05)$. RT: retention time. ND: not detected.

Antioxidant activities: The antioxidant activities of ricegrass and wheatgrass juice extract were analyzed using various methods to represent the different ability to prohibit the oxidation process and expressed as mg pyrogallol equivalent, the most effective phenolic molecules in in vitro antioxidant system and Trolox equivalent, a universal standard (Table 5).

DPPH and ABTS assay were the widely method to determine the ability to scavenge DPPH radical which generated in ethanol and ABTS radical which well-generated in water by giving hydrogen atom and electron, respectively. It was found that wheatgrass juice extract exhibited lightly higher ability to scavenge radical than ricegrass juice extract in both systems $(p<0.05)$. While HRSA is also another system indicated the radical scavenging activity of antioxidant 
molecules which was similarly to those DPPH and ABTS method, even $\mathrm{OH}^{\bullet}$ radical can be found in human body. Wheatgrass juice also expressed higher HRSA activity than ricegrass. FRAP assay is the one which determine ability of antioxidant as reductant. The results revealed that the reducing power of ricegrass juice was slightly lower than wheatgrass juice $(\mathrm{p}<0.05)$.

Phenolic compounds contain hydroxyl groups on the aromatic ring. Due to the resonance property of them, they are able to donate protons and/or electrons to other unstable molecules [25]. Consequently, phenolic compounds in ricegrass and wheatgrass might play important roles in the antioxidant activities. According to the experiment, the high level of phenolic compounds found in ricegrass displayed high antioxidant activities. However, it has been pointed out that not only phenolic molecules but also other compounds such as chlorophyll, ascorbic acid, and organic acids also revealed anti-oxidation ability. Additionally, wheatgrass juice showed greater ability to chelate ferrous ion, almost doubled to that of ricegrass. This may be contributed to the large amount of chlorophyll which is one of the most efficient natural chelating molecules [26]. Das et al. [27] reported that the DPPH scavenging activity of wheatgrass juice is higher when freeze dried where its ascorbic acid is more retained compared to when oven dried. As a result, high level of ascorbic acid and chlorophyll synergizing with phenolic compounds may propose higher antioxidant activities of the wheatgrass juice. While main function of being antioxidant molecules in ricegrass juice was supposed to relate to phenolic compounds.

Table 5. Antioxidant activities of ricegrass and wheatgrass juice extract

\begin{tabular}{|c|c|c|c|}
\hline Method & & $\begin{array}{c}\text { Ricegrass juice } \\
\text { extract }\end{array}$ & $\begin{array}{c}\text { Wheatgrass juice } \\
\text { extract }\end{array}$ \\
\hline \multirow[t]{2}{*}{ DPPH } & mg PYE/g extract & $1.55 \pm 0.10^{b}$ & $2.28 \pm 0.04^{\mathrm{a}}$ \\
\hline & $\mathrm{mg} \mathrm{TE} / \mathrm{g}$ extract & $4.65 \pm 0.12^{b}$ & $5.51 \pm 0.04^{\mathrm{a}}$ \\
\hline \multirow[t]{2}{*}{ ABTS } & mg PYE/g extract & $5.14 \pm 0.06^{b}$ & $5.43 \pm 0.04^{\mathrm{a}}$ \\
\hline & $\mathrm{mg} \mathrm{TE} / \mathrm{g}$ extract & $38.06 \pm 0.38^{b}$ & $39.77 \pm 0.27^{\mathrm{a}}$ \\
\hline \multirow[t]{2}{*}{ HRSA } & mg PYE/g extract & $4.76 \pm 0.05^{b}$ & $9.06 \pm 0.05^{\mathrm{a}}$ \\
\hline & $\mathrm{mg} \mathrm{TE} / \mathrm{g}$ extract & $75.22 \pm 1.11^{b}$ & $164.11 \pm 1.11^{\mathrm{a}}$ \\
\hline \multirow[t]{2}{*}{ FRAP } & mg PYE/g extract & $7.40 \pm 0.01^{\mathrm{b}}$ & $7.78 \pm 0.20^{\mathrm{a}}$ \\
\hline & mg TE/g extract & $35.62 \pm 0.03^{b}$ & $37.45 \pm 0.98^{\mathrm{a}}$ \\
\hline FCA & $\mu \mathrm{mol}$ EDTAE/g extract & $10.47 \pm 0.14^{\mathrm{b}}$ & $25.59 \pm 0.35^{\mathrm{a}}$ \\
\hline
\end{tabular}

Each value was expressed as the mean \pm standard deviation $(n=3)$. Different letters in the same row indicated significant differences $(p<0.05)$. PYE: pyrogallol equivalent. TE: Trolox equivalent. EDTAE: Ethylenediaminetetraacetic acid equivalent.

Nevertheless, antioxidant activities may not only be related to the bioactive molecules but also variable among different cultivars of rice or wheat, growing environment, fertilization, etc. Additionally, the juice from some pigmented rice such as Kum Doisaket, Rice berry and Kum Noi have been previously reported to display higher percentage of DPPH radical scavenging 
activity and FRAP compared to wheatgrass juice due to high anthocyanin content (4). However, the price of those pigmented rice grains was quite high. Though ricegrass juice in this study was produced from rice cultivar Chainat, which was statistically qualified to have lower antioxidant power than wheatgrass juice, there was not a noticeable difference. Furthermore, Chainat1, which is the cheapest rice $(0.5 \$ / \mathrm{kg})$ showed lower cost of production per beneficial in antioxidant activity compared to wheatgrass, of which the seeds roughly cost $3.6 \$ / \mathrm{kg}$ in Thailand. Therefore, Chainat 1 rice is a very promising candidate. Additionally, there are various methods available for the improvement of bioactive compounds which can possibly offer superior antioxidant activities, such as agronomic bio-fortification, seed priming, or using natural and chemical elicitation, while applications to plant food can be further studied.

\section{CONCLUSION}

Although ricegrass juice had a little lower ability on anti-oxidation activity compared to wheatgrass juice, it contained higher level of phenolic acid molecules, including pyrogallol, vanillic acid, and ferulic acid. Moreover, while providing high nutritional values compared to wheatgrass juice, ricegrass juice had a lower production cost. Ricegrass juice can then be developed competitively to wheatgrass juice as antioxidant boosting drink.

Abbreviations: TPC: Total extractable phenolic content; DPPH: 1,1-diphenyl-2-picryl-hydrazyl; ABTS: 2,2'-azino-bis (3-ethylbenzthiazoline-6-sulfonic acid); HRSA: hydroxyl radical scavenging activity; FRAP: Ferric reducing antioxidant power; FCA: Ferric ion chelating activity; Trolox: 6-hydroxy-2,5,7,8-tetramethylchroman-2-carboxylic acid.

Competing interests: The authors have declared that no competing interests exist.

\section{Author's contributions:}

Rattanamanee Chomchan, Ph.D. candidate, is the major investigator, performed all experiments, the analysis and writing the manuscript.

Sunisa Siripongvutikorn, Ph.D. is an Assistant Professor of food technology. She provided vision and conceptualization for the research. She was also contributing to the study design, writing and verified the correction of manuscript.

Panupong Puttarak, Ph.D. is a doctor of pharmaceutical sciences. He is a research coordinator who provided remarks, suggestion as well as verified the correction of manuscript.

Rungtip Rattanapon, M.Sc., is the research coordinator of this work who assisted in performing the experiments and writing the manuscript.

Acknowledgements: The authors would like to express sincerely to Patthalung Rice Research Center, Thailand proving the rice paddy. Also the authors are grateful for the financial support from the Graduate School of Prince of Songkla University and Thailand Education Hub for southern region of ASEAN countries scholarship. 


\section{REFERENCES:}

1. Mendonca-Filho, R.R. In Iqbal Ahmad, F. A., Mohammad Owais (ed.), Modern Phytomedicine: Turning Medicinal Plants into Drugs; Germany. John Wiley \& Sons; 2006

2. Seibold, R. Cereal Grass-What's in it for you. Lawrence, Kansas: PINES International, Inc: 2008.

3. Padalia, S., Drabu, S., Raheja, I., Gupta, A. and Dhamija, M. Multitude potential of wheatgrass juice (Green Blood): An overview. Chron Young Sci. 2010; 1:23-28.

4. Khanthapoka, P., Muangpromb, A. and Sukronga, S. Antioxidant activity and DNA protective properties of rice grass juices. Sci Asia. 2015; 41:119-129.

5. Rattanapon, R., Siripongvutikorn, S., Usawakesmanee, W. and Thongraung, C. Improvement of nutritional value and bioactivity of ricegrass as affected of priming induced by fish protein hydrolysate. Funct Foods Health Disease. 2016; 6:220-233.

6. AOAC. Official Method of Analysis. Association of Official Analytical Chemists. 17th ed, Washington D.C., USA: 2000.

7. Dubois, M., Gilles, K.A., Hamilton, J.K., Rebers, P. and Smith, F. Colorimetric method for determination of sugars and related substances. Anal Chem. 1956; 28:350-356.

8. Nelson, N. Nelson-Somogyi modification colorimetric method for determination reducing sugar. J Biol Chem. 1944; 153:375-380.

9. Arnon, D.I. Copper enzymes in isolated chloroplasts. Polyphenoloxidase in Beta vulgaris. Plant Physiol. 1949; 24:1-10.

10. Lichtenthaler, H.K. and Wellburn, A.R. Determinations of total carotenoids and chlorophylls a and $\mathrm{b}$ of leaf extracts in different solvents. Biochem Soc Trans. 1983; 11:591-592.

11. Sofowora, A. Medicinal plants and traditional medicine in Africa. Ibadan, Nigeria. ;Spectrum Books: 1993

12. Harborne, J. Phytochemical methods. London; Chapman and Hall Ltd.: 1973

13. Singleton, V. and Rossi, J.A. Colorimetry of total phenolics with phosphomolybdicphosphotungstic acid reagents. Am J Enol Viticul. 1965; 16:144-158.

14. Brand-Williams, W., Cuvelier, M.-E. and Berset, C. Use of a free radical method to evaluate antioxidant activity. LWT-Food Sci Technol. 1995; 28:25-30.

15. Arnao, M.B., Cano, A. and Acosta, M. The hydrophilic and lipophilic contribution to total antioxidant activity. Food Chem. 2001; 73:239-244.

16. Benzie, I.F. and Strain, J. The ferric reducing ability of plasma (FRAP) as a measure of "antioxidant power": the FRAP assay. Anal Biochem. 1996; 239:70-76.

17. Ebrahimzadeh, M.A., Nabavi, S. and Nabavi, S. Correlation between the in vitro iron chelating activity and poly phenol and flavonoid contents of some medicinal plants. Pakistan J Biol Sci. 2009; 12:934.

18. Jin, M., Cai, Y., Li, J. and Zhao, H. 1, 10-Phenanthroline-Fe2+ oxidative assay of hydroxyl radical produced by H2O2/Fe2+. Prog Biochem Biophys. 1996; 23:553-555.

19. Kantety, R.V., La Rota, M., Matthews, D.E. and Sorrells, M.E. Data mining for simple sequence repeats in expressed sequence tags from barley, maize, rice, sorghum and wheat. Plant Mol Biol. 2002; 48:501-510. 
20. Tiwari, P., Kumar, B., Kaur, M., Kaur, G. and Kaur, H. Phytochemical screening and extraction: a review. Int Pharm Sci. 2011; 1:98-106.

21. Ashok, S.A. Phytochemical and pharmacological screening of wheatgrass juice (Triticum Aestivum L.). Int J Pharm Sci Rev Res. 2011; 9:159-164.

22. Durairaj, V., Hoda, M., Shakya, G., Babu, S.P.P. and Rajagopalan, R. Phytochemical screening and analysis of antioxidant properties of aqueous extract of wheatgrass. Asian Pacific J Trop Med. 2014; 7:S398-S404.

23. Yaronskaya, E., Vershilovskaya, I., Poers, Y., Alawady, A.E., Averina, N. and Grimm, B. Cytokinin effects on tetrapyrrole biosynthesis and photosynthetic activity in barley seedlings. Planta. 2006; 224:700-709.

24. Berker, K.I., Ozdemir Olgun, F.A., Ozyurt, D., Demirata, B. and Apak, R. Modified Folin-Ciocalteu antioxidant capacity assay for measuring lipophilic antioxidants. J Agri Food Chem. 2013; 61:4783-4791.

25. Vinson, J.A., Su, X., Zubik, L. and Bose, P. Phenol antioxidant quantity and quality in foods: fruits. J Agri Food Chem. 2001; 49:5315-5321.

26. Kephart, J.C. Chlorophyll derivatives - Their chemistry? commercial preparation and uses. Econ Bot. 1955; 9:3-38.

27. Das, A., Raychaudhuri, U. and Chakraborty, R. Effect of freeze drying and oven drying on antioxidant properties of fresh wheatgrass. Int J Food Sci Nutr. 2012; 63:718-721. 